\title{
DOI: 10.7596/taksad.v6i4.1155
}

Citation: Zinnatullina, Z., Khabibullina, L., \& Popp, I. (2017). The Opposition of East and West in the Long Day Wanes Novel by Anthony Burgess. Journal of History Culture and Art Research, 6(4), 623-630. doi:http://dx.doi.org/10.7596/taksad.v6i4.1155

\section{The Opposition of East and West in the Long Day Wanes Novel by Anthony Burgess}

\section{Zulfiya Zinnatullina ${ }^{1}$, Liliya Khabibullina², Ivan Popp ${ }^{3}$}

\begin{abstract}
This year the literary public celebrates $100^{\text {th }}$ anniversary of Anthony Burgess' birth (19171993). The trilogy The Long Day Wanes is among early works of the author, but also the author considers perspective of the East and the West relationship here. In the article we consider the main lines of the characters representing the mother country and colony, also we designate evolution of heroes in the trilogy and we draw a conclusion on as far as the writer departs from the traditional ways the East-common English literature depicting in the first half of the $20^{\text {th }}$ century. It is possible to allocate two tendencies of the East assessment in the trilogy: image of Asians as slowwitted and silly and, on the contrary, strange, difficult representatives of an exotic mentality. There is no uniformity in the image of colonialists. Some Europeans and British feel "at home", being in East space, like culture and mentality of the East, and some represent type of the colonialist treating everything as an object to study. The special attention is deserved by any representatives of "false" identity having lost themselves in someone else's system of values.
\end{abstract}

Keywords: English literature, Burgess, Colonial discourse, Post-colonialism, East, West.

\footnotetext{
${ }^{1}$ Kazan Federal University, Lev Tolstoy Institute of Philology and Intercultural Communication. E-mail: zinzulya@mail.ru

${ }^{2}$ Kazan Federal University, Lev Tolstoy Institute of Philology and Intercultural Communication.

${ }^{3}$ Ural State Pedagogical University.
} 


\section{Introduction}

Anthony Burgess (1917-1993) remains popular author even today. In many respects in his novels he anticipates those tendencies which would only be actively comprehended in culture only at the end of the $20^{\text {th }}$ century. Burgess's trilogy which is entitled The Long Day Wanes (in 1972 three novels Time for a Tiger (1956), The enemy in the Blanket (1958) and Beds in the East (1959) were published under the name The Malayan Trilogy) (Drabble \& Stringer, 1996) is among early works of the author, yet even here he touches a colonial perspective which gains the increasing sharpness over time. Three novels are written under the impression of his own stay in this country which he left in 1959 when doctors suspected he had a brain tumor. In these novels it is possible to observe origin of those problems which will become mainstream in works of the writer for many years. The problem of relationship between the East and West becomes one of them.

\section{Methods}

The trilogy is of interest, first of all, as it answers the questions about relationship of the people, traditional for this perspective, after the colonial era rise (Shevchenko, 2015). According to the western researchers, this segregation is very considerable. For example, A. Massie (2000) notes: "If Kipling and Haggard were poet and propagandist of Empire, Burgess was the amused chronicler of its end". The work from the point of view of considered problems causes numerous associations with George Orwell, Evelyn Waugh, Graham Green's works, etc.

Burgess's novel is progressive for the literature of his time as he avoids sharp division on Us and Others, without representing either the uniform world of Malayans, or the uniform camp of colonists. In the novel possible forms of various worlds intertwining are mainly shown: attempts to naturalize the British (in the second novel), attempts to Europeanize the residents of Malaya, as well as various forms of intra Asian and intra western interactions and mixtures. The identity problem, not only in national, but also in the cultural plan, becomes one of the most essential in the work. At the same time, if late post-colonial works are connected mainly with problems of identity search by representatives of colonial countries, then here before us a problem of self-determination of the other camp representatives stands, the best of them trying to be objective.

\section{Results and Discussion}

The Malayan trilogy allows observing creative evolution of the writer. The first novel, Time for $\boldsymbol{a}$ Tiger gives a clear idea of the author's references. Statement of a problem of the East 
and West goes back to Kipling. Two English characters "conduct" two main Kipling-style subjects, the police officer Nabby Adams grieving for life in India and as a result coming back to Bombay and the martinet Major Rivers remembering service in Africa and propagandizing cruelty (Burgess, 1959). Approach to the solution of the main problem, by recognition of critics, allows to speak also about associations with recently at that time appeared Graham Green's novel Quiet American (DeVitis, 1972). However in Burgess's novel political problems are not developed, also the comic element is less expressed. The problem of British assimilation in Malaya is in many respects connected with a problem of language and is sometimes identified with it. So, Nabby Adams who knows Panjabi and the Indian dialects, cannot and does not want to live in Malaya, aspiring to Bombay. The wife of the protagonist, Fenella Crabbe, feels a stranger in the country which language she does not know. The aspiration of the central hero to assimilate in the country is also connected with the aspiration to learn language. The understanding of the country and statement of one of the main problems of the novel quite traditional for literature of this period, opposition of the East and West as chaos and order is also connected with language: Dere are no rules," smiled Inche Kamaruddin. "Dat is de first ting dat you must learn. Every word is different from every oder word. De words must be learned separately. De English look for rules all de time. But in de East dere are no rules. He he he (Burgess, 1959). At the second, and especially to the third novel, the language aspect weakens, political sharpness amplifies, the number of the characters representing various types of both British, and Malayans increases. However the principle of lack of rules is very important as for the image of the world of the East as world chaotic, so somewhat and for the image of colonists, each of whom shows special type of attitude towards a situation, practically does not duplicate each other.

The East portrait in the trilogy is versatile. Already in the first novel two tendencies of the East assessment are planned: the first is an image of Asians as primitive, pompous and silly beings. Towards this type are generally drawn those representatives of the Malayan people who practise Islam. Their national identity can be various. It is the Panjabi Alladad Khan in the first novel, in the second - the prominent Malayan official Abang, in the third - the Malayan Syed Omar. All representatives of this type have big families whose large number is caused by tradition of polygamy, and not less numerous relatives. The motive of desire in all its meanings becomes the main motive uniting this group. All representatives of this group differ in greed, all of them (except Syed Omar who duplicates Jalil in this respect in the third book) feel attraction to other women besides their wives. For the first two novels it is a classical situation of an inclination to the white woman, the wife of Victor Crabbe. In the third volume the situation becomes complicated and Rosemary embodying type of the emancipated Asian becomes the main sexual object. This type perceived most negatively, shows the 
stability in the world of Malaya as his representatives have numerous posterity. In the third novel Syed Omar's son Syed Hassan takes quite essential place in the work and he becomes one of the chief representatives of future independent country. His ignorance and complacency become a constant subject of author's irony. Representatives (conditionally) of India and Ceylon who become already obviously comic characters in the novel also are drawn towards the same type. It is interesting that than more urgent for this or that character or group of characters division Us-Others by national, confessional or even exclusive principle, especially lowered becomes this character. So, the comic group of eternally drunk idlers is presented in the second novel by Sikhs to whom exclusive accessory is essential, in the third Tamils. They keep together, get into comic situations, but persistently adhere to prejudices and believe in their own exclusiveness.

The second tendency is an image of the East as carrier of exotic strange, unclear, and terrible mentality. The motive of treachery which is not realized by traitors per se becomes the main motive conducting this subject. This group of images is individualized, they are not similar to each other. In the first novel this subject contacts image of the servant Crabbe, the homosexual Ibrahim who constantly robs the owner, and at the end runs from him and pupils of the hero, the Chinese boys, such as Toong Cheong and Shiu Hung who cover own rebellious moods, accusing the teacher Crabbe of initiation of disorders at school. The same subject in the second novel is supported by an image of the cook Ah Wing who hurts the owner by the involuntary associate of communist insurgents, as well as images of Tamil robbers at the beginning of the second novel and, mainly, the Tamil Jaganathan, the deputy of Crabbe accusing him of sympathies for communism. The treachery subject in its different types becomes the dominating subject of the second novel and contacts also image of Rupert Hardman, the English albino who decided to be naturalized in Malaya, having married the local resident who also involuntarily betrays Crabbe, telling Jaganathan about his sympathies for Marxism in the past. In the third book the subject of treachery weakens, being shown in more irregular shape in the history of Crabbe relations with the Chinese boy Robert Loo who is a talented composer, but does not see need for recognition of the talent, disappointing hopes of Crabbe. Here the homosexuality subject declared in the first book which in the first novel noted secret defects of the East is transformed, now designates false charges of perversity to the West.

The special place among images of the second type belongs to the image of Che Normah who represents "reverse side" like the Muslim woman, powerless in society, but omnipotent in a family: Che Normah was a good Malay and a good Muslim. That is to say, her family was Achinese and came from Northern Sumatra and she herself liked to wear European dress 
occasionally, to drink stout and pink gin and to express ignorance about the content of the Koran. The Achinese are proverbially hot-blooded and quick on the draw, but the only knives 'Che Normah carried were in her eyes and her tongue. She gave the lie to the European superstition - chiefly a missionary superstition - that the women of the East are down-trodden. Her two husbands - the first Dutch and the second English - had wilted under her blasts of unpredictable passion and her robust sexual demands. The Communist bullets that had rendered her twice a widow had merely anticipated, in a single violent instant, what attrition would more subtly have achieved (Burgess, 1959).

Both of these types are deprived of reflection. Therefore the problem of any self-identification does not concern diverse representatives of the world of Malaya that receives comic interpretation in images of Tamils in the third novel, nobody of which for this reason can marry and seeks to prevent a marriage of the others. To the problem of self-identification in general any reflection is shown only in characters of those Asian heroes in whose veins other blood, especially blood of Europeans already flows. It is Roper mentioned earlier, Abdul Kadir, mix of the Malayan, Chinese and Dutch who was drawn towards seeking answer to a “dangerous” questions: Why cannot Islam develop a more progressive outlook? (Burgess, 1959).

The problem of identity, search of the place in the world of Malaya is connected in the novel with the world of British and other Europeans whose positions on this question vary from aspiration to leave Malaya immediately (Fenella Crabbe) to the aspiration to merge with it (Hardman). The way of finding the dream is paradoxical. The beauty that is not appreciated in Malaya even by her own husband the poetess Fenella Crabbe is compelled to meet with the Malayan official Abang Hardman which converted to Islam, realizes it as a mistake and is going to run from the East.

The special case of "false" identity when representatives of Europe begin to identify themselves with Asia or on the contrary is presented too. The case of Nabby Adams, the Englishman who best of all felt in India and dreams to return there is interesting in this sense: You're English right enough but you're forgetting how to speak the bloody language, what with traipsing about with Punjabis and Sikhs and God knows what. You talk Hindustani in your sleep, man. Sort it out, for God's sake (Burgess, 1959). Nabby Adams case - not an exception among colonists: But nobody cared, for nobody wanted to think of the place as a home. Nabby Adams thirsted for Bombay, Flaherty yearned for Palestine, Keir would soon be back in Glasgow and Vorpal had a Chinese widow in Malacca (Burgess, 1959).

Rosemary in the third novel of the trilogy becomes a striking example of the "return" result of general mixture. The beauty, whose ideal beauty the author repeatedly calls absurd or 
ridiculous, black, externally true representative of Asia, she grieves about England as about the homeland, dreaming to marry only the Englishman: She had thought of herself living in a nice house in Hampstead or Chiswick, the beautiful mysterious Oriental princess who had married a commoner, who was not above preparing special dishes - exotic and spicy - for her guests, but who otherwise queened it over a household of stolid British servants... She was also, of course, Javanese princess, or Balinese, or Hawaiian. But she was not a colored woman (Burgess, 1959).

As the main carrier of the British national consciousness in the novel the main character, Victor Crabbe acts. That picture of the world which is presented in reasonings of Crabbe and is the main in the novel, though not final. As S. Coale notes in the book about Burgess: "... single character representing order tries to bring stability and understanding to the racially, religiously and culturally confused world around him" (1981). Really, Crabbe tries to bring in the world of Malaya culture and education according to the understanding of this problem. He realizes himself to be the representative of a certain educational, purely British cultural mission, realizing thereby one of the essential parties of national identity.

Under his protection Robert Loo whose music is represented a certain basis of the national and esthetic idea of Malaya becomes deification of these attempts in the third novel. However the reality of the East resists the rationalistic ideas of the West (represented by Crabbe). If in the first novel national and political confusion of Malaya proves more within school, constrained by the British control, then in the third novel, connected with an independence finding era, it is developed in scales of all country: There was, it's true, sort of illusion of getting on when the British were in full control. But self-determination's a ridiculous idea in a mixed-up place like this. There's no nation. There's no common culture, language, literature, religion (Burgess, 1959).

Researchers note a paradoxicality of the main character situation: "Crabbe's move from disillusionment and disaffection to alienation, from dissipation to revulsion, from sordidness and impotence to an absurd death counterpoints the rise of Malaya and contrasts ironically the sudden agony of individual change with the impersonal, maddeningly leisured forward march of events" (Coale, 1981).

Opposition of the East and West as opposition of chaos and order, on one hand, is very close to the author of the novel, but the picture which in plot is objectively developing contradicts within this concept, putting the representative of the British national consciousness in position of the loser. The relations of the hero, as well as other British, with Malaya are already based not so much on the principle Us-Others, but on the principle $I$ - Another which realization leads sometimes to lack of consent between colonists which are included in the concept Other 
and representatives of their own race, absorbed by that chaos of the East in which the main character hoped to bring an his own political and cultural order. The protagonist loses in many respects owing to the emotional involvement into a situation in Malaya, owing to trying to be useful to the country, imposing his own idea of life.

Other, lowered type of the colonialist is represented by images of the Americans succeeding British. So, Temple Haynes, the American appearing in the third volume of the novel shows the "scientific" way to Malaya. He "studies" the country only in one area (without knowing language, studies phonetics). Absurdity of such approach is shown by a comic sketch in which the young American shows to inhabitants various images, being surprised why they call everything in one word while one of British knowing language does not explain him that this word is "picture". Haynes the representative of race, according to Crabbe, a race with as litde sense of guilt as history (Burgess, 1959) does not consider it necessary to understand, fall in love with the country, into which he arrived, seeing it only as an object of study. This image probably, goes back to Alden Payl's image from Green's novel Quiet American (Greene, 1955). In some sense the position of Americans in the novel is only the position of British driven to the point of absurdity (we will remember scientific interest of Crabbe in the language in the first novel).

The author creates a pseudo-utopian picture of reconciliation of races in the novel final, in any case, the younger generation, on the basis of culture unification, that culture which Burgess perceives as the culture Americanized, culture of consumer society (youth fashion, popular music), showing, as well as in many English anti-Utopias, not the demand of a component of cultural diversity, but history in the modern Americanized civilization (for example, we meet the same picture in the novel of the writer).

\section{Conclusion}

Thus, in the trilogy, though the picture of the diverse world of Malaya is created, all possible types of intra east and intercivilization mixture are accented (false identity), but the overall binary picture of the world remains urgent (such picture of the world is common to many works of the author of this period, for example The Wanting Seed (1973)). The opposition the West-East remains unresolved in the relation Asia-Europe, and, paradoxically, America-Asia due to loss of religious, spiritual culture which important components were in the relations: sense of guilt before the oppressed nation, attempt of cultural diversity preservation, special image of the country. 
In conclusion we can express solidarity with the ideas of R. Morris who speaks about specifics of the image of the Malayan world in the novel being connected with the fact that the author, as well as his hero, himself does not fully understand this world: "Revealing Malaya never meant explaining it - either to us or to his hero” (Morris, 1971). It is represented to us that having taken an essential step forward in comparison with the compatriots in the image of the world of the East, Burgess, nevertheless, does not go beyond the western system of thinking and estimation.

\section{Acknowledgements}

The work is performed according to the Russian Government Program of Competitive Growth of Kazan Federal University.

\section{References}

Burgess, A. (1973). The Wanting Seed. London: Heinemann.

Burgess, A. (1959). The long day wanes. London: Heinemann.

Coale, S. (1981). Anthony Burgess. New York.

DeVitis, A. (1972). Anthony Burgess. New York.

Drabble, M. \& Stringer, J. (1996). The Concise Companion to English Literature. New York.

Greene, G. (1955). The Quiet American. London: Heinemann.

Massie, A. (2000). The Malayan Trilogy. Anthony Burgess Newsletter \#3. The Anthony Burgess Centre.

Morris, R. K. (1971). The Consolations of Ambiguity. An Essay On the Novels of Anthony Burgess. Columbia: University of Missouri Press.

Shevchenko, A. R. \& Nesmelova, O. O. (2015). Gender identity in British postcolonial novel: Hanif Kureishi's "The Buddha of Suburbia". Social Sciences, 10(4), 421-425. 